\title{
SEPULUH STRATEGI DALAM PEMECAHAN MASALAH MATEMATIKA
}

\author{
Syahlan \\ Pendidikan Matematika FKIP-UISU, Medan, syahlanbaak@gmail.com
}

\begin{abstract}
Abstrak. Salah satu tujuan dalam pembelajaran matematika adalah agar siswa mampu menyelesaikan permasalahan. Masalah yang diajukan tidak hanya terbatas pada masalah rutin, tetapi dapat berupa masalah tidak rutin. Masalah tersebut menjadi tantangan bagi siswa untuk dipecahkan. Masalah tidak rutin menjadi sulit diselesaikan karena tidak dapat diselesaikan menggunakan konsep dan prinsip matematika yang umum. Dalam menyelesaikan masalah diperlukan strategi yang tepat dengan mengombinasikan segala konsep dan prinsip matematika yang dikuasai siswa. Melalui artikel ini diharapkan guru maupun siswa akan memiliki pemahaman sehingga dapat memilih diantara 10 strategi yang sesuai dalam pemecahan masalah matematika.
\end{abstract}

Kata Kunci: Strategi, Masalah Matematika, Pemecahan Masalah

\section{Pendahuluan}

Kehidupan menawarkan dua hal yang berlainan, yaitu suka atau duka. Kedukaan umumnya disebabkan oleh adanya masalah yang dihadapi. Masalah haruslah dihadapi dengan bijak dan harus diselesaikan dengan cara yang baik. Pembelajaran merupakan suatu kegiatan yang bertujuan untuk membantu siswa menghadapi dunia nyata. Oleh karena itu, pembelajaran matematika tidak dapat terlepas dari kegiatan pemecahan masalah. Pembelajaran seharusnya dikaitkan dengan upaya dan melatih siswa untuk berpikir dalam memecahkan masalah. Idealnya, pembelajaran matematika seharusnya menawarkan masalah untuk diselesaikan sebagai latihan bagi siswa dalam membangun dan mengembangkan kemampuan kognitif siswa.

Pemecahan masalah merupakan salah satu dari lima tujuan pembelajaran matematika. Menurut NCTM (2000), ada lima tujuan yang menjadi fokus dalam kemampuan belajar matematika, yaitu 1) kemampuan pemecahan masalah, 2) kemampuan penalaran dan pembuktian, 3) kemampuan koneksi, 4) kemampuan komunikasi, dan 5) kemampuan representasi. Masalah merupakan pertanyaan yang harus dijawab dengan baik. Pertanyaan yang diajukan dapat berupa pertanyaan rutin maupun pertanyaan tidak rutin. Melalui masalah, siswa diajak untuk berpikir dan mencari sebab-sebab masalah itu timbul.

Berdasarkan sebab-sebab yang ada sebagai informasi awal, siswa harus berupaya untuk menyelesaikan masalah sebagai akibatnya. Ada 10 cara yang dapat dipilih siswa dalam memecahkan masalah matematika yang dihadapi. Artikel ini menawarkan berbagai strategi yang efektif dalam menyelesaikan masalah matematika sehingga siswa dapat dengan bijak memilih cara yang tepat.

Masalah merupakan hal yang selalu kita hadapi. Berbagai kejadian terkadang menjadi masalah yang harus diselesaikan dengan segera. Demikian pula dalam belajar, berbagai masalah disajikan kepada siswa untuk diselesaikan dalam upaya membelajarkan siswa. 
Tidak setiap pertanyaan dapat disebut sebagai masalah dan tidak semua masalah yang diberikan akan dapat membelajarkan siswa. Masalah yang dimaksud adalah pertanyaan atau soal yang tidak dapat diselesaikan dengan menggunakan aturan-aturan perhitungan biasa (prosedur rutin). Masalah yang dapat membelajarkan siswa adalah masalah yang memberikan tantangan kepada siswa yang tidak dapat dipecahkan oleh suatu prosedur rutin yang telah diketahui oleh siswa.

Masalah dalam matematika haruslah menantang, perlu adanya suatu prosedur baru yang memerlukan pengorganisasian pengetahuan yang dimiliki siswa selama ini. Artinya bahwa siswa harus dapat mengombinasikan segala konsep yang telah diketahuinya dan yang terkait masalah, lalu membentuk suatu konsep baru sehingga masalah yang diberikan dapat dipecahkan. Pernyataan tersebut sejalan dengan pendapat Cooney (Budhayanti, dkk, 2008) bahwa "suatu pertanyaan akan menjadi masalah hanya jika pertanyaan itu menunjukkan adanya tantangan yang tidak dapat dipecahkan oleh suatu prosedur rutin yang sudah diketahui oleh si pelaku".

Soal cerita merupakan salah satu bentuk masalah yang sering disajikan dalam pembelajaran matematika. Siswa ditantang untuk memahami masalah tersebut sehingga siswa dapat mengumpulkan informasi-informasi yang dibutuhkan, seperti: apa yang diketahui dan apa yang menjadi masalah. Melalui informasi tersebut, siswa akan dapat menentukan konsep yang cocok maupun konsep yang berkaitan dengan masalah untuk dapat merencanakan penyelesaiannya menggunakan model matematika. Hasilnya, model yang dibuat akan membantu siswa dalam menyelesaikan masalah yang diberikan.

Berdasarkan pendapat di atas, maka yang dimaksud dengan masalah dalam matematika adalah suatu pertanyaan yang menggugah kita sehingga menjadi tertantang untuk menyelesaikannya menggunakan segenap pengetahuan (konsep dan prinsip matematika) yang telah dimiliki sebagai dasar dalam membentuk konsep baru hingga dapat diselesaikan.

\section{Proses Pemecahan Masalah Matematika}

Masalah yang diberikan harus mampu diamati dari berbagai sudut pandang sehingga akan dapat diketahui prinsip dari masalah itu. Polya (1975: 6) mengungkapkan bahwa pemecahan masalah merupakan kegiatan yang dilakukan dengan mengubah cara pandang seseorang terhadap masalah untuk mengidentifikasi masalah dan selanjutnya memutuskan cara penyelesaian masalah. Menurutnya, solusi yang diberikan tidak hanya merupakan jawaban untuk memecahkan masalah tetapi juga memuat prosedur yang harus dilakukan untuk mendapatkan jawaban. Untuk itu, pemberi jawaban harus memberikan langkah-langkah penyelesaiannya secara detail.

Ada empat tahap yang harus dilakukan siswa untuk menyelesaikan masalah yang diberikan, yaitu: 1) memahami masalah (understanding the problem), 2) merencanakan cara penyelesaiannya (devising a plan), 3) melaksanakan rencana yang telah dibuat (carrying out the plan), 4) melihat kembali seluruh proses yang dilakukan (looking back) (Polya, 1975: 6-14). Untuk melaksanakan keempat tahap penyelesaian masalah ini dibutuhkan ketelitian dan kesabaran, yakni pada setiap tahap yang dilakukan diperlukan refleksi sehingga menjadikannya semacam siklus. Misalkan setelah memahami masalah, akan melanjutkannya 
dengan membuat rencana dengan memilih strategi penyelesaian. Ketika gagal membuatnya, maka kembali kepada masalah dan mencari informasi tambahan yang relevan untuk dapat mendukung penerapan strategi tersebut agar dapat digunakan.

Tahap pertama yang harus dilakukan siswa adalah menentukan hal-hal yang diketahui dengan tepat dan apa yang harus diselesaikan. Untuk itu, siswa terkadang perlu mempresentasikan masalah tersebut ke dalam bentuk gambar, tabel, maupun notasi matematika. Selain itu, mengetahui apa yang harus diselesaikan membantu siswa mengetahui arah yang menjadi tujuan penyelesaian masalah tersebut sehingga memudahkan siswa membuat rencana penyelesaian dengan menetapkan strategi yang tepat.

Tahap kedua yang harus dilakukan adalah mencari alternatif jawaban yang mungkin dapat digunakan untuk menyelesaikan masalah tersebut. Pada tahap ini, kreativitas, pengetahuan terkait masalah, mental belajar, dan konsentrasi siswa sangat dibutuhkan untuk menentukan berbagai cara penyelesaian masalah. Ada lima cara yang dapat digunakan dalam mencari cara penyelesaian masalah, yaitu 1) mencoba-coba (guess and check), 2) membuat/menemukan pola (look for pattern), 3) membuat dan menyusun daftar secara sistematis (make a systematic list), 4) membuat dan menggunakan gambar maupun model (make and use a drawing or model), 5) mempertimbangkan/meniadakan suatu kemungkinan yang dapat terjadi (eliminate possibilities) (Sheffield dan Cruikshank, 1996: 35).

Pemilihan strategi ini umumnya disesuaikan dengan masalah yang diajukan. Beberapa cara lebih efektif dibandingkan cara yang lain pada suatu masalah. Namun pada masalah lainnya, cara tersebut malah tidak dapat digunakan. Oleh karena itu harus jeli dalam memilih strategi yang tepat dan cocok digunakan untuk menyelesaikan suatu masalah. Dalam hal meniadakan suatu kemungkinan, ada tiga cara yang dapat diterapkan. Menurut Sheffield dan Cruikshank (1996: 37), cara tersebut adalah 1) menyelesaikan masalah secara mundur/dari belakang (working backwards), 2) menyelesaikan masalah secara langsung (acting out the problem), dan 3) mengubah cara pandang terhadap masalah (changingyour point of view).

Tahap ketiga adalah melaksanakan sesuai dengan apa yang telah direncanakan. Tahap ini cukup mudah dilaksanakan karena yang dibutuhkan hanyalah kesabaran. Prosedur yang telah ditetapkan dilakukan menurut aturan-aturan yang berlaku sesuai dengan konsep algoritma matematika sehingga masalah yang diajukan telah benar-benar terselesaikan. Peran guru pada tahap ini sangat penting dalam membantu siswa menyelesaikan masalahnya. Berbagai pertanyaan dapat diajukan guru untuk membantu siswa menemukan arah penyelesaian masalah dengan benar dan juga sebagai upaya untuk memberikan umpan balik kepada siswa.

Alternatif penyelesaian masalah yang dibuat siswa belum tentu merupakan konsep yang formal. Untuk itu pada tahap terakhir (keempat) ini, siswa diajak untuk melakukan penyelidikan terhadap semua prosedur penyelesaian masalah yang dibuat. Berdasarkan hal tersebut, siswa akan dapat menghubungkan konsep-konsep yang diketahuinya dengan konsep lain sebagai pengetahuan yang baru serta dapat mengembangkan kemampuan mereka dalam menyelesaikan masalah yang diberikan. Keempat langkah proses penyelesaian masalah oleh Polya dapat dipresentasikan dalam bentuk diagram berikut. 


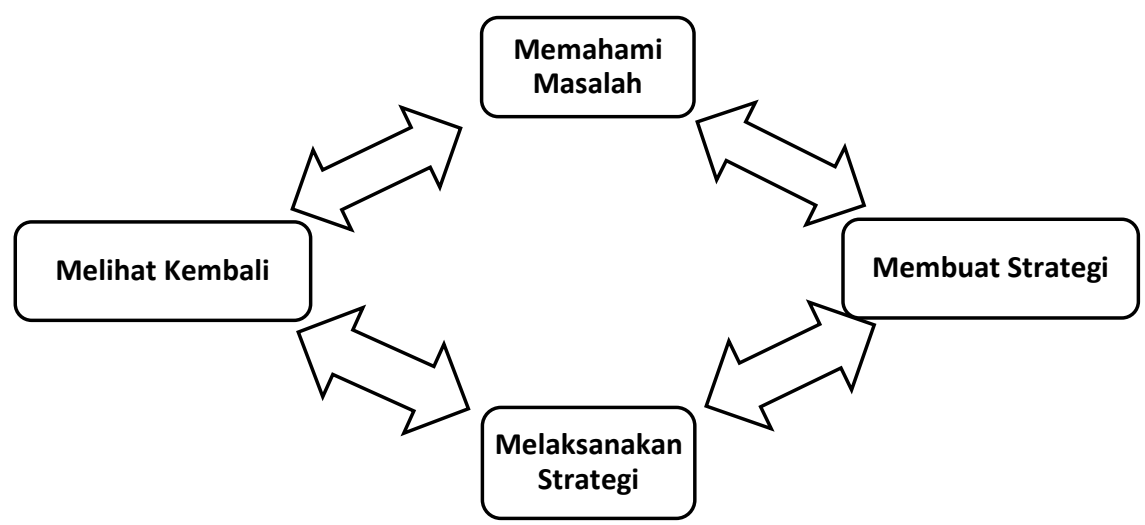

Gambar 1. Langkah proses pemecahan masalah oleh Polya

\section{Strategi Pemecahan Masalah Matematika}

Langkah kedua dalam memecahkan masalah adalah merencanakan strategi yang efektif. Banyak strategi yang dapat digunakan untuk menyelesaikan masalah, diantaranya adalah menyelesaikan masalah secara mundur/dari belakang (working backwards), menyelesaikan masalah secara langsung (acting out the problem), dan mengubah cara pandang terhadap masalah (changing your point of view) seperti yang diungkapkan Sheffield dan Cruikshank (1996: 37) dalam bukunya. Selain itu, menurut Posamentier (2009) dalam bukunya mengungkapkan bahwa pada tingkat dasar (grades 3-6) ada 9 strategi yang dapat digunakan, sedangkan untuk tingkat menengah (grades 6-12). Posamentier (1998) menyatakan ada 10 strategi yang dapat digunakan dalam memecahkan masalah. Sepuluh strategi pemecahan masalah tersebut diuraikan sebagai berikut.

\subsection{Menyelesaikan Masalah Secara Mundur/dari Belakang}

Masalah rutin umumnya dimulai dari konsep awal dan siswa ditugaskan menyelesaikannya. Lalu bagaimana jika sebaliknya(diberikan jawaban akhirnya untuk mendapatkan nilai-nilai awalnya)?Untuk menyelesaikan masalah seperti ini siswa dapat menyelesaikannya secara terbalik pula, dimana siswa bergerak mundur ke belakang untuk mendapatkan hasil-hasil awalnya.

Contoh masalah 1:

Ibu mempunyai 10 apel, 15 jeruk dan 20 pisang yang akan disajikan dalam beberapa piring dengan komposisi yang sama. Berapa piring yang harus disediakan Ibu?

Alternatif solusi:

Masalah di atas, mensyaratkan bahwa dalam setiap piring harus diisi oleh 3 macam buah(apel, jeruk, dan pisang) dan tidak boleh ada tersisa. Seandainya kita membagikannya dalam piring, kita akan kesulitan menentukan dengan tepat banyak piring yang harus disediakan. Untuk itu, kita harus menyelesaikannya secara terbalik. Kita perlu membagi setiap jenis buah ke dalam beberapa bagian dalam jumlah yang sama, sehingga diketahui: 
Apel sejumlah 10 disajikan dalam $2 \times 5$ piring $=5 \times 2$ piring

Jeruk sejumlah 15 disajikan dalam $3 \times 5$ piring $=5 \times 3$ piring

Pisang sejumlah 20 disajikan dalam $2 \times 10$ piring $=4 \times 5$ piring $=5 \times 4$ piring

$$
=10 \times 2 \text { piring }
$$

Karena banyak piring yang sama untuk setiap jenis buah adalah 5 piring, maka diketahui bahwa penyelesaian yang tepat adalah bahwa harus ada 5 piring yang harus disediakan untuk disajikan, dan setiap piring harus diisi oleh 2 apel, 3 jeruk, dan 4 pisang.

\subsection{Menemukan Pola}

Matematika merupakan konsep yang teratur dan memiliki pola yang tetap. Sehingga beberapa masalah matematika pastilah akan mengandung pola-pola yang kemudian dapat dikembangkan menjadi konsep matematika yang utuh. Oleh karena itu, harus diteliti permasalahannya dan menyatakan pola tersebut untuk membentuk konsep matematikanya.

Contoh masalah 2:

Suhu di dalam kulkas sebelum dihidupkan $29^{\circ} \mathrm{C}$. Setelah dihidupkan suhunya turun $3^{\circ} \mathrm{C}$ setiap 5 menit. Berapakah suhu di dalam kulkas setelah 30 menit?

Alternatif solusi:

Permasalahan ini menyatakan bahwa setiap 5 menit suhu dalam kulkas turun $3^{\circ} \mathrm{C}$.

Berarti setelah 10 menit suhunya turun menjadi $3^{\circ} \mathrm{C}+3^{\circ} \mathrm{C}=2 \times 3^{\circ} \mathrm{C}$.

Karena 10 menit $=2 \times 5$ menit, itu artinya bahwa setiap kelipatan 5 menit maka suhunya turun sebanyak hasil kali kelipatan 5 menit dengan $3^{\circ} \mathrm{C}$.

Atau dapat dinyatakan bahwa $n \times 5$ menit $=n \times 3^{\circ} \mathrm{C}$.

Dengan demikain, 30 menit $=6 \times 5$ menit $=6 \times 3^{\circ} \mathrm{C}=18^{\circ} \mathrm{C}$.

Pada awalnya suhu kulkas adalah $29^{\circ} \mathrm{C}$ dan turun sebesar $18^{\circ} \mathrm{C}$, maka

$29^{\circ} \mathrm{C}-18^{\circ} \mathrm{C}=11^{\circ} \mathrm{C}$.

Jadi setelah 30 menit suhunya adalah $11^{\circ} \mathrm{C}$.

\subsection{Mengubah Cara Pandang Terhadap Masalah}

Suatu masalah dapat dipandang dari berbagai sudut pandang seseorang sehingga masalah itu dikatakan bernilai relatif, dapat menjadi mudah atau sebaliknya dapat menjadi sulit. Demikian pula halnya dengan masalah matematika. Jangan hanya terpaku pada satu konsep saja sehingga tidak terjebak. Dengan mengubah sudut pandang, akan ditemukan konsep lain yang tersembunyi yang memungkinkan untuk menyelesaikannya dengan mudah. 
Contoh masalah 3:

Perhatikan gambar di samping!

Jika $K, L, M, N$ merupakan titik tengah masing masing garis $A D, A B, B C$, dan $C D$ dari suatu persegi $A B C D$.Apabila luas persegi $A B C D$ adalah $6 p^{2}$, berapakah luas persegi $K L M N$ ?

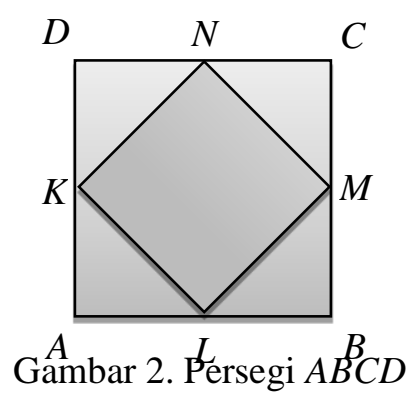

Alternatif solusi:

Jika diperhatikan, kita akan merasa sulit untuk menyelesaikan masalah ini apalagi jika kita tidak menguasai Teorema Pythagoras untuk menghitung panjang sisi-sisi pada persegi $K L M N$. Selain itu, kita juga harus menentukan panjang sisi persegi $A B C D$ terlebih dahulu.

Tetapi jika kita memandang masalah dari sudut pandang lain, yaitu dengan membagi bangun persegi tersebut menjadi beberapa bagian, maka akan diperoleh seperti gambar di samping berikut ini.

Terlihat bahwa persegi $A B C D$ terdiri atas 8 bagian dan persegi $K L M N 4$ bagian sama besar sehingga perbandingan

$$
A B C D: K L M N=8: 4=2: 1 \text {. }
$$

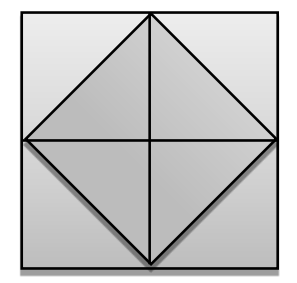

Dengan demikian, luas persegi $K L M N=\frac{1}{2} \times 6 p^{2}=3 p^{2}$.

\subsection{Menggunakan Analogi/Pengandaian Sederhana}

Karena matematika merupakan konsep yang teratur dan memiliki pola yang tetap, dapat digunakan pengandaian sederhana untuk mengungkapkan konsep yang umum dari konsep yang khusus atau sebaliknya. Pengandaian dapat mengungkapkan pola khusus sehingga memungkinkan membuat konsep yang umum.

Contoh masalah 4:

Suatu pekerjaan dapat diselesaikanoleh 32 pekerja dalam waktu 81 hari. Setelah dikerjakan 15 hari, pekerjaan itu dihentikan selama 18 hari. Jika kemampuan bekerja setiap orang sama dan agar pekerjaan tersebut selesai sesuai jadwal semula, maka banyak pekerja tambahan yang diperlukan adalah....

Alternatif solusi:

Andaikan bahwa banyaknya pekerjaan itu adalah hasil kali banyaknya pekerja dengan banyaknya waktu yang ada, maka banyaknya pekerjaan adalah

$$
n\left(\mathrm{P}_{\mathrm{s}}\right)=32 \times 81=2592 .
$$

Banyaknya pekerjaan selama 15 hari adalah

$$
n\left(\mathrm{P}_{1}\right)=32 \times 15=480 .
$$

Karena pekerjaan dihentikan selama18 hari, maka sisa tenggat waktu adalah

$$
81-15-18=81-(15+18)=81-33=48 \text { hari }
$$

sedangkan banyak pekerjaan yang tersisa adalah

$$
2592-480=2112
$$


sehingga jumlah pekerja yang dibutuhkan untuk menyelesaikan pekerjaan adalah

$2112: 48=44$ orang pekerja.

Jadi pekerja tambahan yang diperlukan adalah selisih jumlah pekerja sebelum dan sesudah libur, yaitu $44-32=12$ orang.

\subsection{Menggunakan/Mempertimbangkan Kondisi yang Ekstrim}

Beberapa masalah yang terjadi terkadang lebih mudah dipahami jika kita mengasumsikannya dalam kondisi paling ekstrim (jika perlu meniadakan kondisi tersebut). Misalkan saja suatu hal yang terjadi dianggap berada pada kondisi awal (pada titik nol) atau bahkan dapat juga dianggap sebagai kondisi yang mustahil. Dengan mengasumsikannya secara demikian, permasalahan tersebut dapat diselesaikan.

Contoh masalah 5:

Sebuah mobil bergerak dengan kecepatan tetap $55 \mathrm{~km} / \mathrm{jam}$. Sebuah mobil lain tepat berada $\frac{1}{2} \mathrm{~km}$ di belakangnya. Tepat setelah 1 menit kemudian, mobil kedua menyusulnya. Berapakah kecepatan mobil kedua tersebut?

Alternatif solusi:

Jika kita mengamati masalah tersebut, kita hanya dapat menemukan informasi yang kurang berarti, yaitu bahwa mobil pertama bergerak tetap $55 \mathrm{~km} / \mathrm{jam}$.Mobil kedua berapa $\frac{1}{2} \mathrm{~km}$ dibelakangnya dan setelah 1 menit mobil kedua menyusul mobil pertama.Kita tidak mungkin menyatakan kecepatan mobil kedua berdasarkan informasi yang diperoleh di atas.Untuk itu, kita perlu mengasumsikan masalah tersebut dalam kondisi yang ekstrim.Karena mobil pertama bergerak tetap (konstan), kita dapat mengasumsikan bahwa mobil itu bergerak dengan kecepatan $0 \mathrm{~km} / \mathrm{jam}$.Berdasarkan informasi kedua dan ketiga, kita dapat menyatakan bahwa mobil kedua mampu bergerak sejauh $\frac{1}{2} \mathrm{~km}$ dalam waktu 1 menit. Itu artinya bahwa kecepatan mobil kedua adalah $\frac{1}{2} \mathrm{~km} /$ menit atau $30 \mathrm{~km} / \mathrm{jam}$. Kecepatan mobil kedua pastilah $30 \mathrm{~km} / \mathrm{jam}$ lebih cepat dari mobil pertama sehingga kecepatan mobil kedua adalah $85 \mathrm{~km} / \mathrm{jam}(30 \mathrm{~km} / \mathrm{jam}+55 \mathrm{~km} / \mathrm{jam})$.

\subsection{Membuat Gambaran}

Masalah yang terjadi dapat diilustrasikan dalam bentuk lain seperti gambar, grafik, maupun tabel untuk mempermudah kita menentukan penyelesaiannya. Dengan bantuan gambar, grafik, maupun tabel, kita dapat menyusun pola yang tepat sehingga informasi yang diperoleh lebih berarti. 
Contoh masalah 6:

Untuk melindungi kebunnya dari hewan liar, Pak Karto membuat pagar kawat di sekeliling kebunnya yang berbentuk persegi. Seandainya luas kebun Pak Karto adalah $64 \mathrm{~m}^{2}$ dan setiap 1 meter dipasangi tiang pagar penyangga kawat, berapa banyak tiang yang diperlukan Pak Karto untuk memagari kebunnya?

Alternatif solusi:

Beberapa informasi yang diketahui adalah bahwa kebun Pak Karto berbentuk persegi dengan luas $64 \mathrm{~m}^{2}$ sehingga diketahui bahwa panjang sisi kebun tersebut adalah $8 \mathrm{~m}$.

Karena hendak dipasangi tiang di sekeliling kebun, maka keliling kebun Pak Karto adalah $4 \times 8$ meter atau sama dengan 32 meter. Lalu, benarkah bahwa banyak tiang yang diperlukan adalah 32 buah? Untuk membuktikannya, kita dapat mengilustrasikan masalah tersebut dalam bentuk gambar sebagai berikut.

\begin{tabular}{|cccccccc}
\hline $\mathrm{X}$ & $\mathrm{X}$ & $\mathrm{X}$ & $\mathrm{X}$ & $\mathrm{X}$ & $\mathrm{X}$ & $\mathrm{X}$ & $\mathrm{X}$ \\
$\mathrm{X}$ & & & & & & & $\mathrm{X}$ \\
$\mathrm{X}$ & & & & & & & $\mathrm{X}$ \\
$\mathrm{X}$ & & & & & & & $\mathrm{X}$ \\
$\mathrm{X}$ & & & & & & & $\mathrm{X}$ \\
$\mathrm{X}$ & & & & & & & $\mathrm{X}$ \\
$\mathrm{X}$ & & & & & & & $\mathrm{X}$ \\
$\mathrm{X}$ & $\mathrm{X}$ & $\mathrm{X}$ & $\mathrm{X}$ & $\mathrm{X}$ & $\mathrm{X}$ & $\mathrm{X}$ & $\mathrm{X}$ \\
\hline
\end{tabular}

Gambar 3. Kebun Pak Karto

Dengan demikian, diketahui bahwa banyak tiang yang dibutuhkan untuk memagari kebun Pak Karto adalah 28 buah tiang, bukan 32 buah tiang.

\subsection{Melakukan Ujicoba (trial-error)}

Beberapa masalah dalam kehidupan sehari-hari dapat diselesaikan dengan melakukan ujicoba, seperti misalnya membuat warna tertentu dengan menggunakan campuran warna dasar. Strategi ini mungkin bukan termasuk dalam prosedur matematika, tetapi konsep seperti ini dapat digunakan untuk memecahkan masalah tertentu yang penyelesaiannya membutuhkan waktu yang lama jika diselesaikan secara matematika atau jika penyelesaiannya menjadi lebih rumit. Ujicoba yang digunakan haruslah menggunakan pemikiran yang baik.Setelah melakukan ujicoba, jika hasilnya gagal, dapat melalukan ujicoba lainnya hingga dapat diselesaikan. 
Contoh masalah 7:

Pada saat ujian, Tuti diberikan 20 soal pilihan ganda. Jika Tuti menjawab benar diberikan skor 5, jika menjawab salah diberikan skor (-2), dan jika tidak menjawab diberikan skor 0 . Jika diketahui skor Tuti adalah 44 dengan beberapa soal yang tidak dijawab, berapakah banyak soal yang tidak dijawab Tuti?

Alternatif solusi:

Seandainya kita menggunakan konsep matematika, kita dapat mengasumsikan bahwa ada tiga variabel yaitu soal dijawab dengan benar $(x)$, soal dijawab tetapi salah $(y)$, dan soal tidak dijawab $(z)$ sehingga dengan menggunakan konsep aljabar diperoleh:

$$
\begin{array}{ll}
x+y+z & =20 \\
5 x-2 y+0 z & =44
\end{array}
$$

Bagaimana kita dapat menyelesaikan permasalahan tersebut?

Umumnya, untuk menyelesaikan bentuk persamaan linier tiga variabel diperlukan 3 persamaan linier. Karena kita hanya mempunyai 2 persamaan di atas, maka perlu strategi lain untuk memecahkannya. Lakukan percobaan untuk menentukan hasil-hasilnya sebagai berikut.

1) Ambil kemungkinan dimana jika jumlah soal benar $\times 5$ menghasilkan skor lebih besar dari 44, misalkan 10 .

2) Tentukan jumlah soal salah $\times(-2)$ menghasilkan skor 44 .

3) Tentukan banyak soal yang tidak dijawab.

Tabel 1. Uji Kemungkinan Jawaban Ujian Tuti

\begin{tabular}{|c|c|c|c|}
\hline $\begin{array}{c}\text { Jumlah Benar } \\
\times \mathbf{5}\end{array}$ & $\begin{array}{c}\text { Jumlah Salah } \\
\times(-\mathbf{2})\end{array}$ & $\begin{array}{c}\text { Tidak dijawab } \\
\mathbf{\times 0}\end{array}$ & Skor total \\
\hline $10 \times 5=50$ & $3 \times(-2)=-6$ & $20-(10+3)=7$ & 44 \\
\hline $11 \times 5=55$ & $* *$ & $* *$ & $* *$ \\
\hline $12 \times 5=60$ & $8 \times(-2)=-16$ & $20-(12+8)=0$ & 44 \\
\hline$* *$ & $* *$ & $* *$ & $* *$ \\
\hline
\end{tabular}

Berdasarkan ujicoba tersebut, diketahui bahwa ada dua kemungkinan yang dapat dijadikan jawabannya, yaitu bahwa soal yang tidak dijawab Tuti ada 7 soal atau tidak ada satupun soal yang tidak dijawab. Karena pada soal dinyatakan bahwa ada soal yang tidak dijawab Tuti, maka banyak soal yang tidak dijawab Tuti ada 7 soal.

\subsection{Mempertimbangkan Segala Kemungkinan}

Strategi ini hampir sama dengan prinsip yang digunakan dalam kegiatan ujicoba (trial and error). Perbedaannya adalah ketika terdapat kemungkinan lain yang dapat dijadikan jawaban, maka kita harus melakukan pemeriksaan terhadap kemungkinan tersebut seperti yang terdapat pada contoh masalah 6 dan 7 . Perlu mempertimbangkan kemungkinan- 
kemungkinan tersebut sehingga dapat menyatakan dengan pasti solusi yang tepat dari permasalahan tersebut.

Contoh masalah 8:

Jika pembilang dan penyebut suatu pecahan ditambahkan 1, maka pecahan itu menjadi $\frac{1}{2}$. Adapun bila masing-masing pembilang dan penyebut dikurangi 1, maka pecahan itu menjadi $\frac{1}{3}$. Apakah bilangan pecahan yang dimaksud?

Alternatif solusi:

Misalkan kita nyatakan bahwa bilangan pecahan tersebut adalah $\frac{a}{b}$.

Dari masalah diperoleh informasi bahwa:

$$
\begin{aligned}
\frac{a+1}{b+1} & =\frac{1}{2} \\
\text { dan } & \frac{a-1}{b-1}=\frac{1}{3}
\end{aligned}
$$

Ini berarti bahwa pecahan $\frac{1}{2}$ dan $\frac{1}{3}$ merupakan bentuk pecahan yang paling sederhana sehingga pecahan yang senilai dari $\frac{1}{2}$ dan $\frac{1}{3}$ adalah

$$
\begin{gathered}
\frac{1}{2}=\frac{2}{4}=\frac{3}{6}=\frac{4}{8}=\frac{5}{10}=\frac{6}{12}=\cdots \\
\text { dan } \\
\frac{1}{3}=\frac{2}{6}=\frac{3}{9}=\frac{4}{12}=\frac{5}{15}=\cdots
\end{gathered}
$$

Karena pecahan tersebut mengalami dua operasi yaitu ditambah 1 dan dikurangi 1 , maka hasil dari operasi tersebut pastilah berselisih 2. Diantara kedua pecahan yang memiliki selisih 2 pada pembilang dan penyebutnya adalah $\frac{4}{8}$ dan $\frac{2}{6}$ sehingga:

$$
\text { dan } \begin{aligned}
\frac{a+1}{b+1} & =\frac{4}{8} \\
\frac{a-1}{b-1} & =\frac{2}{6}
\end{aligned}
$$

sehingga diperoleh $a=3$ dan $b=7$.

Jadi pecahan yang dimaksud adalah $\frac{3}{7}$. 


\subsection{Mengorganisir Data}

Suatu masalah umumnya disertai oleh beberapa informasi penting yang menuntun kita pada jawaban yang dikehendaki.Salah satu strategi yang dapat kita gunakan adalah mengorganisir data tersebut, mengolahnya, dan menyatakannya sebagai suatu kesimpulan yang pasti.

Contoh masalah 9:

Anto, Budi, dan Doni sama-sama menggemari renang. Anto berenang setiap 4 hari sekali, Budi berenang setiap 5 hari sekali, dan Doni berenang setiap 7 hari sekali. Jika pada tanggal 3 Agustus 2015 mereka sama-sama berenang, tanggal berapakah mereka akan sama-sama berenang kembali?

Alternatif solusi:

Karena Anto berenang setiap 4 hari sekali, Budi berenang setiap 5 hari sekali, dan Doni berenang setiap 7 hari sekali, maka kita dapat menyatakannya dalam bentuk kelipatan persekutuan terkecil dari 4,5 , dan 7 , yaitu:

$$
\begin{aligned}
& \text { Anto }=\{4,8,12,16,20,24,28,32, \ldots, 140, \ldots, 280, \ldots\} \\
& \text { Budi }=\{5,10,15,20,25,30, \ldots, 140, \ldots, 280, \ldots\} \\
& \text { Doni }=\{7,14,21,28,35,42,49, \ldots, 140, \ldots, 280, \ldots\}
\end{aligned}
$$

Karena paling cepat mereka bertemu 140 hari kemudian, dimana bulan Agustus berjumlah 31 hari, bulan September berjumlah 30 hari, bulan Oktober berjumlah 31 hari, bulan Nopember berjumlah 30 hari, dan Desember berjumlah 31 hari, sehingga totalnya ada 153 hari.

Setelah dikurangi 3 hari, diperoleh bahwa sampai akhir bulan Desember ada 150 hari.

Karena paling cepat mereka bertemu 140 hari kemudian, maka mereka akan bertemu pada tanggal 21 Desember 2015.

\subsection{Menggunakan alasan logis}

Terkadang suatu masalah memiliki banyak kemungkinan jawaban. Tidak semua jawaban tersebut dapat dinyatakan sebagai jawaban karena alasan yang logis. Untuk itu, kita harus mempertimbangkan kemungkinan jawaban yang ada berdasarkan alasan yang logis seperti yang telah kita lakukan pada saat menyelesaikan masalah 8 di atas.

Perhatikan contoh masalah 8 di atas:

Ketika kita melihat banyaknya kemungkinan pecahan senilai dari $\frac{1}{2}$ dan $\frac{1}{3}$, kita harus melihat kemungkinan tersebut dengan menggunakan alasan logis bahwa setelah ditambah 1 menjadi $\frac{1}{2}$ dan setelah dikurangi 1 menjadi $\frac{1}{3}$. Ini berarti bahwa pembilangnya bernilai di antara pembilang pecahan senilai dari $\frac{1}{2}$ dan $\frac{1}{3}$. Demikian pula untuk penyebutnya. Dengan 
demikian, dapat kita simpulkan bahwa bilangan pembilang tersebut berada diantara pecahan senilai dari $\frac{1}{2}$ dan $\frac{1}{3}$ dimana selisih keduanya adalah 2 .

Pecahan senilai dari $\frac{1}{2}$ dan $\frac{1}{3}$ yang mungkin adalah $\frac{4}{8}$ dan $\frac{2}{6}$ sehingga kita akan memperoleh pecahan $\frac{3}{7}$ sebagai jawaban karena 3 berada di antara 2 dan 4 .Demikian pula 7 berada di antara 6 dan 8 .

\section{Kesimpulan}

Strategi yang tepat memungkinkan kita mencapai tujuan secara efisien. Dalam memecahkan masalah matematika, kita membutuhkan strategi yang tepat sehingga permasalahan dapat diselesaikan dengan baik dan mudah. Berdasarkan pembahasan di atas, maka dapat disimpulkan hal-hal sebagai berikut.

1. Masalah bukanlah sesuatu yang harus dihindari, tetapi sesuatu yang harus dihadapi dan diselesaikan dengan bijak.

2. Masalah matematika memungkinkan kita untuk melatih cara berpikir kita melalui tahapan-tahapan pemecahan masalah, mulai dari: a) memahami masalah, b) merencanakan strategi yang tepat, c) melaksanakan strategi yang telah dibuat/direncanakan, dan d) memeriksa kembali apakah masalah telah benar-benar dapat diselesaikan.

3. Dalam menyelesaikan masalah, ada 10 alternatif strategi yang dapat digunakan sehingga hasilnya efisien, yaitu: a) menyelesaikan masalah secara mundur/dari belakang, b) menemukan pola, c) mengubah cara pandang terhadap masalah, d) menggunakan analogi sederhana, e) menggunakan/mempertimbangkan kondisi ekstrim, f) membuat gambar, g) melakukan ujicoba (trial and error), h) mempertimbangkan segala kemungkinan yang ada, i) mengorganisir data, dan j) menggunakan alasan logis.

\section{Daftar Pustaka}

Budhayanti, Baskoro, Roostanto, dan Simanullang. 2008. Pemecahan Masalah Matematika; Bahan Ajar Cetak. Jakarta: Direktorat Jenderal Pendidikan Tinggi.

NCTM.2000. Principles and Standards for School Mathematics. Virginia: NCTM, Inc.

Polya, G. 1975. How to Solve It: a New Aspect of Mathematical Method. Diperbarui oleh Conway, John, H. 2004. Princeton: Princeton Science Library.

Posamentier, A. S. dan Krulik, S. 1998. Problem Solving Strategies for Efficient and Elegant Solutions Grades 6-12: A Resource for the Mathematics Teacher. Calofirnia: Hawker Brownlow Education.

Posamentier, A. S. dan Krulik, S. 2009. Problem Solving in Mathematics Grade 3-6: Powerful Strategies to Deepen Understanding. Corwin, A Sage Company.

Sheffield, L. J. dan Cruikshank, D. E. 1996.Teaching and Learning; Elementary and Middle School. New Jersey: Prentice Hall, Inc. 